\title{
Guy Debord and the Integrated Spectacle
}

\author{
Julian Eagles
}

The emergence of the so-called 'anti-globalization' movement saw a renewed interest, amongst some associated with this movement, in the thought of the Situationists. In the 1960s Guy Debord[1] argued that modern capitalism had become a society of the spectacle. Debord divided the spectacle into two forms, the diffuse and the concentrated. In the 1980s Debord put forward the idea that modern capitalist society had now become an 'integrated spectacle'. This notion of an integrated spectacle, developed in Debord's later oeuvre, has often received less attention than the concept of spectacle outlined in his earlier writings. In this article, therefore, I make the integrated spectacle my central focus of attention.

In his book Comments on the Society of the Spectacle Debord suggests that:

\begin{abstract}
These Comments are sure to be welcomed by fifty or sixty people... It must also be borne in mind that a good half of this interested elite will consist of people who devote themselves to maintaining the spectacular system of domination, and the other half of people who persist in doing quite the opposite. Having, then, to take account of readers who are both attentive and diversely influential, I obviously cannot speak with complete freedom... Some elements will be intentionally omitted; and the plan will have to remain rather unclear. Readers will encounter certain decoys, like the very hallmark of the era ([1988] 1990: 1-2).
\end{abstract}

In the article I examine the concept of the integrated spectacle -as best I can, bearing in mind Debord's remarks cited above- by undertaking an 'immanent critique'. The article is divided into three sections. In the first section, I make an assessment of the integrated spectacle as a global concept. In the second section, I examine how the integrated spectacular society functions. In the third section, I discuss the issue of resistance to the integrated spectacle.

\section{The Integrated Form of Spectacle}

Towards the end of the 1980s - in a context in which the 'cold war' had entered its final phase - Debord argued that the two forms of spectacle he had previously formulated, the diffuse and the concentrated,[2] had combined into an 'integrated spectacle'.[3] This 'rational combination' took place 'on the basis of a general victory of the... diffuse [spectacle]' (Debord 1990: 8). The concentrated spectacle, Debord claims, preferred 'the ideology condensed around a dictatorial personality', whilst the diffuse spectacle, which 'represented the Americanisation of the world', required 'wage-earners to apply their freedom of choice to the vast range of new commodities now on offer' (1990: 8). Debord suggests that since '[ $t$ ] he disturbances of 1968', which failed to overturn modern capitalist society, 'the spectacle has thus continued to gather strength' (1990: 2-3). He also remarks that 'the spectacle today is certainly more powerful than it was before' (1990: 4). Further, he writes 'that the spectacle's domination has succeeded in raising a whole generation moulded to its laws' (1990: 7). 'The commodity', he maintains, 'is beyond criticism' (1990: 21).

For Debord, 'the integrated spectacle is characterised by the combined effect of five principal features: incessant technological renewal; integration of state and economy; generalised secrecy; [4] unanswerable lies; an eternal present' (1990: 11-12). Furthermore, Debord claims that 'the integrated spectacle has been pioneered by France and Italy' 
(1990: 8), and that ' $\mathrm{t}$ ] he emergence of this new form [of spectacle] is attributable to a number of shared historical features' (1990: 8-9). These include, 'the important role of the Stalinist party and unions in political and intellectual life, a weak democratic tradition, the long monopoly of power enjoyed by a single party of government, and the need to eliminate an unexpected upsurge in revolutionary activity' (1990: 9).[5]

What, then, are we to make of Debord's claim that 'the integrated spectacle has been pioneered by France and Italy'? And how does this relate to Debord's claim that following the 'general victory' of the diffuse over the concentrated spectacle, an integrated spectacle 'has since tended to impose itself globally'? (1990: 8)

To explore this further, let us consider how the five principal features of the integrated spectacle relate to the previous two forms of spectacle. It can be argued, I think, that four of the five principal features are common to both diffuse and concentrated spectacular societies; namely, integration of state and economy, generalized secrecy, unanswerable lies, an eternal present.[6] Incessant technological renewal is, however, something which Debord implies was a feature of spectacular society in its diffuse rather than concentrated form.[7]

Debord, I think, is arguing that although diffuse and concentrated spectacular societies had differences between them, indeed differences sufficient to categorize particular societies into either form of spectacle, these two forms of spectacle are nevertheless not fundamentally opposed to one another. What Debord seems to suggest, then, in his later oeuvre,[8] is the following: that some of those features common to both forms of spectacle became modified following the 'general victory' of the diffuse over the concentrated spectacle. For example, Debord claims that in relation to 'unanswerable lies',[9] the 'concept of disinformation was recently imported from Russia' (1990: 44) (prior to the collapse of the USSR). Thus, a concept or practice that arose and developed in a concentrated spectacular society, once applied in societies that had been categorized as diffuse, modifies the feature 'unanswerable lies' (see Debord 1990: 44-9).

So, although Debord sees the integrated spectacle as a form of spectacle that 'has been established...on the basis of a general victory of the form which had shown itself stronger: the diffuse' (1990: 8), it is not a case of the diffuse form spreading unaltered to those societies that were part of the concentrated spectacle. Rather, the 'rational combination' of the two forms has led to the emergence of societies around the world that are a hybridization of diffuse and concentrated forms. Indeed, if we consider - as I argued above - that four of the five principal features of the integrated spectacle were common to both diffuse and concentrated societies, it follows that there were elements of the concentrated spectacle already present within the diffuse spectacle and vice versa.

If we are, then, to make any sense of Debord's integrated spectacle, it could be argued that whilst the historical features shared by France and Italy are not necessary for the development of the integrated spectacle within most (or even all) societies around the world, what is necessary is the existence of an Americanized system of mass production and consumption. For Debord, I think, it is this that makes possible the incessant technological renewal of modern capitalist society. Furthermore, the reason for Debord's identification of France and Italy as pioneers of the integrated spectacle arguably comes down to the following: that the 'principal features' he identifies, in the particular historical context of these two societies, had altered, post 1968, to such an extent that a new form of spectacle could be distinguished. And that context was one which had the following features: a highly developed (Americanized) system of commodity production and consumption, a strong 'Stalinist party and unions..., a weak democratic tradition, the long monopoly of power enjoyed by a single party of government, and the need to eliminate an unexpected upsurge in revolutionary activity' (1990: 9) - namely the events of 1968. To take one of the principal features, 'an eternal present', a technique associated with this, which was prominently utilized and developed in (concentrated) Stalinist societies, was, according to Debord, the '[use of] police methods to transform perception' ([1967]1995: para 105). Yet this technique, which was developed within France and Italy after 1968, has been modified such that '[t] he police in question... are of a completely new variety [emphasis added]' (1995: 8).[10]

If we hold, then, to the argument outlined above, I think it is possible to view the integrated spectacle as a global concept. That said, the following question now arises: how does the (global) integrated spectacle reproduce itself? It is to this issue that I shall now turn.

\section{| Pleasure, Unpleasure and the Integrated Spectacle}

The Situationists - in their heyday - considered that the spectacle is able to perpetuate itself, in part, through manipulating the individual's desire to experience pleasure (see Debord 1995: paras 59, 66 \& Vaneigem [1967]1994: 
138). In this regard the following could be argued: given that the Situationists believe that the individual can attain self-realization through the pleasurable passions to be creative, to play and to love (see Vaneigem 1994: ch 23), and that '[p]leasure is the principle of unification' (1994: 253),[11] the spectacle is able to reproduce itself by harnessing the pleasurable passions or real erotic desires of the individual (see below).[12] Spectacular society, then, through manipulating the individual's desire to experience pleasure, achieves an illusory unity.

Now, I think the way in which the Situationists imagine that the spectacle reproduces itself, remains, on a general level, the same throughout their oeuvre -early or late.[13] That said, the particular manner in which the spectacle modifies the individual's passions is portrayed, in Debord's later oeuvre, as a more intensive process of repression than the Situationists previously imagined. Arguably, this stronger repression refers to the following (although I must stress that this is not made explicit in Debord's later writings): that as the capitalist system, by the 1980s, produced a greater range of commodified goods and reified roles for people to consume, there emerged, for the mass of the population, niche markets for commodities.

Spectacular society, through offering a huge range of 'image-objects'[14] (alienated goods and roles) for consumption, [15] manipulates the individual's sexual instinct. It stimulates - via images - the individual's real desires, but only permits 'pseudo-gratification'.[16] The individual, whose passions are subjected to a type of repression as they are 'rechannelled...in roles' (Vaneigem 1994: 133) or through the consumption of goods, experiences controlled pleasure; the spectacle, therefore, frustrates the realization of the individual's real desires.[17] Post 1968, modern capitalism, due to changes in mass production techniques, offers a greater variety of image-objects from which to choose than hitherto. And it is through the niche marketing of commodities, it seems, that the spectacle has become more sophisticated in its manipulation of the individual's real desires. Yet this requires - although this is potentially problematic for the spectacle - that the individual becomes more aware of the specificity of his or her desires (see section III). That said, the spectacle continues, nevertheless, to thwart genuine self-realization, as it reroutes the individual's authentic desires towards commodified forms of leisure or play.[18]

In addition to modern capitalism's manipulation of the individual's sexual instinct, I think it can also be argued that the integrated spectacle manipulates, as did the spectacle (in a minor way) in its diffuse form and (to a greater extent) in its concentrated version, the instinct of self-preservation to help perpetuate itself (see below).[19] With this in mind, let us explore in greater detail how the spectacle in its integrated form functions.

In his Comments on the Society of the Spectacle, Debord brings the notion of fear more to the fore.[20] He claims that:

Going from success to success, until 1968 modern society was convinced it was loved. It has since had to abandon these dreams; it prefers to be feared (Debord 1990: 82).

What Debord implies here, I think, is that the 1968 rebellion in France revealed -particularly to the ruling class - that the majority of the population was not deeply integrated into spectacular society. In addition to this, Debord suggests that the spectacle 'has at least sufficient lucidity to expect that its free and unhindered reign will very shortly lead to a significant number of major catastrophes' (1990: 62). He points to an ecological catastrophe, citing the dangers associated with nuclear power plants and the destruction of the earth's ozone layer by CFC gases (1990: 34-8, 62). He also mentions an economic catastrophe, 'in banking, for example' (1990: 62). For Debord, then, the circumstances of the post 1968 era have been conducive for fear to become a major factor in relation to the reproduction of spectacular society.[21]

Surveillance organizations, which lurk in the background ready to strike at organized opposition, make people fear the consequences of dissent. They ensure that proletarian[22] opposition to spectacular society is 'eliminated' (Debord 1990: 80) or 'dispersed' (1990: 84). Debord maintains that:

Under spectacular domination people conspire to maintain it, and to guarantee what it alone would call its well-being. This conspiracy is a part of its very functioning (1990: 74).

So there is, in part, a conspiratorial element to the functioning of the integrated spectacle.[23] As Debord writes:

[Specialists in surveillance] can now employ traditional methods for operations in clandestine milieux: provocation, infiltration, and various forms of elimination of authentic critique in favour of a false one which will have been created for this purpose (1990: 53-4).

Indeed, in its quest to crush dissent 'the highest ambition of the integrated spectacle is still to turn secret agents 
into revolutionaries, and revolutionaries into secret agents' (Debord 1990: 11). Take the case of the undercover policeman Mark Kennedy. From 2003 to 2010, Kennedy, a British policeman under the alias Mark Stone, infiltrated various anti-capitalist groups across Europe associated with the 'anti-globalization' movement. He was unmasked as a police agent just before a trial was due to begin in which the state sought to prosecute a group of protestors with whom Kennedy was associated; they were accused of planning an occupation of Ratcliffe power station in the UK.[24] The conspiratorial side to the spectacle (of which Debord speaks), should not, however, be seen as something unified and omnipotent. Rather, 'thousands of plots in favour of the established order tangle and clash almost everywhere' (1990: 82). 'Surveillance', Debord suggests, 'spies on itself, and plots against itself' (1990: 84).

Debord also alludes, arguably, to the idea that frightening or alarming images, circulated by the mass media, manipulate the individual's instinct of self-preservation and make him or her experience fear. As he writes:

The spectacle makes no secret of the fact that certain dangers surround the wonderful order it has established. Ocean pollution and the destruction of equatorial forests threaten oxygen renewal; the earth's ozone layer is menaced by industrial growth; nuclear radiation accumulates irreversibly. It merely concludes that none of these things matter (Debord 1990: 34). [25]

It would appear, then, that the mass media - and I think Debord's use of the term 'spectacle' here does denote the mass media - on the one hand generate fear by highlighting specific dangers that pose a threat to the individual's very existence; and yet on the other hand soothe these fears by suggesting the insignificance of such 'dangers'.[26] On my reading, it is through the media raising the issue of catastrophic dangers to humankind, that the individual's instinctual impulse of self-preservation is stimulated such that he or she experiences a feeling of extreme fear. In turn, as the spectacle portrays these dangers or risks as unimportant, the individual is relieved of the pain or unpleasure generated by a rise in instinctual tension.

This argument could, I think, be applied to the US government's 'war on terror'; a 'war' launched following the September 11, 2001 attacks in the USA. Periodically, the media raise the issue of new terror plots; this makes the individual feel extremely anxious that his or her existence is threatened by upcoming acts of terror. As the terror attacks fail to materialize, the media subsequently suggesting the insignificance of this particular threat or danger, the individual experiences a feeling of relief. For example, in July 2002 a warning by the state authorities that the Golden Gate Bridge in San Francisco was a possible target of a terrorist plot (although no such attack subsequently took place), gained widespread media coverage.[27] Further, it could be argued that when, occasionally, terror attacks do actually take place, the individual's feelings of extreme anxiety are soothed as the media report that the state authorities are hunting those responsible for such attacks. For instance, the much publicized US drone aircraft missile attacks which assassinate 'suspected militants',[28] or the use of special forces to assassinate Islamist militants, such as Osama Bin Laden, who, on 2 May 2011, was killed by a US Naval Seals unit in Abbottabad, Pakistan.[29]

At this point it is pertinent to note that Debord points to the 'dissolution of logic' in spectacular society (1990: 27); or put another way, to the rise within the conditions of modern capitalist society, of a technological rationality which appears as reason itself.[30] In this connection, the Situationists referred to the spectacle's power of recuperation; that is to say, modern capitalism's ability to absorb - via the process of commodification - that which emerges outside of its domain. As Debord writes, '[spectacular discourse] isolates all it shows from its context, its past, its intentions and its consequences' (1990: 28). In other words, anything that becomes subject to the rule of the commodity-form becomes equivalent and its importance or otherwise is veiled.[31] It is the logic of the commodity form, then, and not some conspiracy or dictatorship, which has facilitated the emergence of the media's illogical language. As the commodity form has impacted itself upon images and information, these things have become increasingly fragmented; indeed, separated from their context, past and so on, to such a degree that most people are unable to make any real sense of them. Therefore, in a society in which the commodity-form rules over lived experience, most people lack 'the ability immediately to perceive what is significant and what is insignificant or irrelevant' (1990: 30).[32]

Debord claims that 'the dissolution of logic has been pursued by... means...linked to the mass psychology of submission' (1990: 27). Here, Debord alludes to the notion that the spectacle manipulates the individual's instinctual drives to aid the smooth functioning of modern capitalism. To unpack this a bit further, I shall now make a few comments about Wilhelm Reich's The Mass Psychology of Fascism (1933), in which he dealt with the issue of society's manipulation of the instincts, as this should help to clarify Debord's thought.[33]

Writing in the 1930s, Reich saw the family as the main social institution that socialized the individual. Reich argued that '[the authoritarian family] becomes the factory in which the state's structure and ideology are molded' 
([1933] 1991: 30). He suggests that the family's '[moral inhibition of the child's natural sexuality] has a crippling effect on man's rebellious forces because every vital life-impulse is now burdened with severe fear' (1991: 30). For Debord, however, it is agencies external to the family that are now the central socializing forces -especially the mass media (see Debord [1978] 2003: 136-37). With this difference in mind, let us now see how Reich's ideas about fear and the instincts compare with those of Debord.

In contrast to Reich's claim that '[m]an's authoritarian structure...is basically produced by the embedding of sexual inhibitions and fear in the living substance of sexual impulses' (1991: 30), Debord and the Situationists do not, I think, imagine that spectacular society turns people into conformist worker-consumers through encumbering the sexual instinct with severe fear. Rather, they imply that this instinctual drive is manipulated in such a way that the real desires which derive from this drive are re-routed towards the spectacle's image-objects. For the Situationists, then, spectacular society, by harnessing - via images - the individual's sexual instinct to reproduce itself, is left in a precarious position: it might be subverted by proletarians if they come to realize their real erotic desires. [34] Indeed, this is what the Situationists claim had taken place in France during 1968. According to Debord, it was the events of 1968 that led spectacular society, which 'until 1968... was convinced it was loved', '[to prefer] to be feared' (1990: 82).

For the Situationists, the spectacle is able to perpetuate itself through manipulating the individual's desire to experience pleasure. Yet, if we consider that when the spectacle manipulates the sexual instinct the individual's (real) desires are not burdened with severe fear, but rather redirected towards 'pleasurable' spectacular roles and consumer goods, then I think that this may, in part, account for the Situationists' tremendous optimism concerning the prospects for proletarian revolution throughout their earlier thought. Such optimism, however, disappears in Debord's later oeuvre.

To explore this further, let me briefly make a few comments about Freud's theory of the instincts and his model of the psyche. Freud referred to the self-preservation instinct in relation to the ego and the sexual instinct in relation to id. The ego is that part of the individual's psyche that observes the reality-principle; the id, the pleasure-principle. [35] Freud suggests, in this regard, that the ego operates according to the reality principle - seeking instinctual gratification by adjusting to the facts of the external world - in order to ensure the maximization of pleasure; or, put another way, to ensure that the individual overcomes a state of unpleasure.

With this in mind, it could be argued that fear plays the following role in the functioning of the integrated spectacle. Given that Debord and the Situationists assume that the spectacle's system of mass consumption functions through harnessing the individual's pleasurable desires which stem from the sexual instinctual drive: and that this system of consumption could no longer function if this vital drive became burdened with severe fear. Moreover, given that Debord claims that the events of 1968 revealed how vulnerable the spectacle was to proletarian subversion, the spectacular system has, it seems, managed to remain in existence by generating fear through manipulating the individual's instinct of self-preservation to a greater extent than prior to the rebellion of 1968.[36] By developing in this way, the system has become able to counteract more effectively the potentially subversive erotic desires of (proletarian) individuals.

For Debord, I think, the system of mass consumption, prior to the events of 1968, functioned as follows: it tapped the (real) erotic desires of the individual, and then repressed these desires as they were rechanneled through the consumption of spectacular goods and roles. The system was, nevertheless, extremely vulnerable to 'proletarian revolution'.[37] What the uprising of 1968 in France showed, for the Situationists, was that modern capitalist society had been temporarily subverted by the 'new proletariat'.[38] Such subversion took place as proletarians sought an authentic realization of their erotic desires which had been awakened but were not then successfully repressed, by the spectacle. After 1968, as I argued above, the spectacle, due to alterations in mass production techniques, refined the way in which its system of mass consumption manipulated individuals' passions. Through developing, for the mass of the population, niche markets for commodities, modern capitalism has, in a sense, become more responsive to the diversity of human desires. Yet according to the terms of Situationist theory the spectacle still blocks genuine self-realization as it re-routes the individual's authentic desires towards commodified goods and roles. The integrated spectacle, then, although more sophisticated in its harnessing of human erotic desire, nevertheless, remains vulnerable to proletarian rebellion (see section III).

Now, if we consider that both those parts of the individual's psyche Freud termed the id and the ego seek to overcome a state of instinctual tension - that is strive to maximize pleasure or overcome a state of unpleasure - then it appears that, within the terms of Debord's theory, it is through harnessing the individual's sexual instinctual drive as well as self-preservation drive that the integrated spectacle is able to function successfully. Without drawing strength from the individual's instinctual impulse of self-preservation, to counter the (real) erotic desires that the spectacle 
taps to re-route towards its image-objects, spectacular society would remain extremely vulnerable to 'proletarian revolution'. Therefore, arguably, as the media publicize catastrophic dangers which threaten humankind and in turn stimulate the self-preservation instinct such that the individual experiences a feeling of extreme fear, the spectacle is able, so to speak, to pitch the ego against the id. This is, I think, what Debord may be alluding to when he claims that

until 1968 modern society was convinced it was loved. It has since had to abandon these dreams; it prefers to be feared. It knows full well that 'its innocent air has gone forever' (1990: 82).

\section{| The Integrated Spectacle and Resistance}

Debord's view of the spectacle, outlined in his later oeuvre from the 1980s, is more bleak and pessimistic than the earlier Situationist vision. By the 1980s, the process of deindustrialization, which had begun in the early 1970 s in the industrially advanced world, had led to a decline in large-scale workers' struggles in the sphere of production. Furthermore, with improvements in transport, communications and the introduction of computers into the production process, companies were able 'to vary output at short notice to meet changing demands' (Hobsbawm 1994: 404). In such circumstances, the development of niche markets, for the mass of the population, subjected people to an intensified mystification. Yet, although Debord claims that modern capitalist society's powers of mystification have gained in strength since 1968,[39] I do not think that he believes that people have become perfectly reified. Put another way, he considers, I think, that there are limits as to the extent to which the spectacle can control the passions of individuals. [40] Indeed, I think he continues to imagine that proletarian revolution[41] against the spectacle is a possibility; a remote possibility, but a possibility nonetheless.[42] Towards the end of Comments on the Society of the Spectacle, Debord makes the following remark:

We must conclude that a changeover is imminent and ineluctable in the coopted cast who serve the interests of domination, and above all manage the protection of that domination. In such an affair, innovation will surely not be displayed on the spectacle's stage. It appears instead like lightning, which we know only when it strikes (1990: 88).

Just prior to the section I have quoted, Debord suggests that the consolidation of spectacular domination is analogous to the 'great changes in the art of war' which came about following the French Revolution (1990: 857). He cites the change from soldiers being '[kept in] ranks and firing on command', to soldiers being 'deployed in extended order, firing at will as they advanced on the enemy' (1990: 86-7). Now, if we assume that the 'coopted cast' that Debord refers to in the quotation is an allusion to worker-consumers, and that these worker-consumers - like the soldiers - are no longer so highly regimented but rather consumers who are encouraged to be more aware of their individuality, of their desires, then I think it is possible to read the cited passage as follows.

Spectacular society, to reproduce itself, has become more sophisticated in harnessing the individual's real desires. Whereas previously a more limited selection of commodities was available for consumption, with the development of niche markets for commodities this requires, in a sense, that each consumer be encouraged to develop a greater awareness of his or her individuality. In other words, for the spectacle to tap the individual's passions and re-route them towards the more diverse range of alienated goods and roles now offered, it needs to make each individual become more aware, than hitherto, of the specificity of his or her desires. The spectacle, then, is compelled to move away from conditioning individuals to develop rather similar desires for commodities. This means that the spectacle encounters the following problem: as proletarians are encouraged to express more readily their individuality, albeit through commodified forms of leisure or play, potentially, at least, they will not be quite as conformist as they were when there was a more narrow selection of spectacular commodities available.[43] So, in this sense, 'the coopted cast' of worker-consumers have the potential to create the 'innovation' (or revolutionary transformation) which Debord suggests, 'will... not be displayed on the spectacle's stage' (1990: 88). [44]

Furthermore, as the Situationists' conception of the proletariat includes not only worker-consumers but also socially marginalized groups, let us consider the following: given that an uprising by marginalized youths, for the Situationists, constitutes an instance of a proletarian rebellion, then arguably, this might open up a further possibility for Debord's later theory to account for revolutionary change. Such youths could be seen as a 'catalyst' for a more widespread rebellion involving worker-consumers (see Debord 1995: para 115 \& Vaneigem 1994: 242).[45] Indeed, towards the end of 2005 there was an uprising by youths from the banlieue which shook France. In addition, in 
England, during August 2011, disaffected youths rioted in various cities, looting shops and destroying property. Like the rioters of Watts in Los Angeles during 1965, who Debord believed had '[taken] modern capitalist propaganda, its publicity of abundance, literally' (Knabb ed. 2006: 197), these youths, through the act of looting, achieved 'the most direct realization of the distorted principle, "To each according to his false needs"” (Knabb ed. 1989: 155). To quote Debord:

They want to possess now all the objects shown and abstractly accessible, because they want to use them. In this way they are challenging their exchange-value... Through theft and gift they rediscover a use that immediately refutes the oppressive rationality of the commodity... (Knabb ed. 2006: 197)

That said, I think Debord believes that proletarian revolution against the integrated spectacle - involving marginalized groups and worker-consumers - is merely a slim possibility. For Debord, the spectacle's powers of mystification post 1968 have strengthened. Nevertheless he imagines, it seems, that there remains a chance albeit remote - that a majority of proletarians may someday spontaneously rebel against reification and overthrow spectacular society. Furthermore, this emphasis on spontaneity gives rise to a marked tension in Debord's later thought between the following two central claims (a tension that was lessened to some extent in the Situationists' earlier oeuvre through the intervention of a non-spectacular revolutionary avant-garde). That is to say, (1) the claim that modern capitalist society has strong powers of domination and mystification - powers that have gained in strength since 1968; and (2) the claim that proletarian revolution against the spectacle is a possibility.

Debord claims that the integrated spectacle's powers of domination have increased to the point whereby spectacular society 'has eliminated every organised revolutionary tendency' (1990: 80). Further, he claims that authentic dissent[46] against the spectacle (whether that of dissenters with a highly developed revolutionary consciousness or otherwise) has been 'dispersed' (1990: 84). By making such claims Debord is, I think, pushed towards a more 'spontaneous' conception of proletarian revolution. That is to say, Debord becomes increasingly reliant on the spontaneous component of the Situationists' vision of revolution.[47] Yet adhering to such a conception brings with it the risk that Debord's theory will pull itself apart, given that he supposes that those who practise détournement[48] (diversion/subversion) may or may not have a revolutionary consciousness.[49] And for the majority to attain such a consciousness, to combat the recuperative power of the spectacle, the assistance of a revolutionary avant-garde group would be required.[50]

That said, it could be argued that the scattering or atomization of authentic dissent might now be counteracted by the use of 'new' technologies, such as the internet and mobile phones, which Debord, who died in 1994, does not mention. Given that these 'new' technologies appear, at present, to be difficult to police, it might be suggested that such technologies can now assist the linkage of those in opposition to capitalist society. Indeed, the use of the internet to help mobilize anti-capitalists - whether active nihilists, those with a proto-revolutionary consciousness or those with an advanced revolutionary (Situationist) consciousness [51] - has been seen with the 'anti-globalization' movement: this brought together dissenters against a variety of international summits of world leaders (such as World Bank, IMF, G8 meetings and so on). Also, the internet has been used to mobilize the 'occupy wall street' movement, which began as an occupation of Zuccotti Park in New York City's Wall Street financial district on 17 September 2011 and then spread to many other cities in the US and around the world. [52] Of course, provided these movements are anti-hierarchically organized, engage in subversive play, do not put forward proposals for the reform of the capitalist system and so on, they can, according to Debord's theory, be viewed as expressions of authentic dissent; that is to say, they stand in opposition to the spectacle and its recuperators (whether reformist politicians, business, hierarchical 'revolutionary' parties and so on).

Furthermore, marginalized youths in London and various other cities in England made use of social networking sites via various 'new' technologies during the August 2011 riots. Some of those involved in the events used an encrypted communication system on BlackBerry mobile phones. Whilst originally developed primarily to provide a secure method of communication for 'business users',[53] some of the rioters used BlackBerry Messenger to communicate with each other and attain some degree of organization during the rebellion. Put another way, they subjected a 'new' technology, developed for capitalist business people, to what Debord termed détournement. Once again, provided these rebellious youths organize themselves, during such events, anti-hierarchically and play subversively (through, for instance, looting[54] - 'which instantly destroys the commodity as such') (Knabb ed. 1989: 155), their rebellion can be considered to be in opposition to the spectacle. However, should they turn to a creed such as nationalism (of one kind or another) or become seduced by hierarchical 'revolutionary' parties and so on, 
this would strengthen the spectacle again.

Therefore, if we assume that some 'new' technologies, when subjected to détournement, can help those opposed to the integrated spectacle to overcome their dispersal or atomization, then the introduction of this new element into the theory could lessen the tension between Debord's two central claims (outlined above): and, enhance it, to some extent, as a theory of social change. Yet, should the 'new' technologies used by genuine dissenters become more susceptible to police surveillance and control, the tension in Debord's theory would remain marked.

\section{Endnotes}

1. Guy Debord was a member of the Situationist International (SI) which existed from 1957 to 1972. The SI was formed by 'artists' associated with various European artistic avant-garde organizations. Up until the early 1960s the SI concerned itself with culturally subversive activities; following this the group developed a more 'political' strategy to realize the unification of art and life. The group published twelve issues of the magazine Internationale situationniste. The group's two major theorists were Guy Debord and Raoul Vaneigem. Debord's The Society of the Spectacle and Vaneigem's The Revolution of Everyday Life were published just prior to the May 1968 uprising in France.

2. In The Society of the Spectacle Debord claims that " $t]$ he diffuse...spectacle is associated with the abundance of commodities, with the undisturbed development of modern capitalism' ([1967] 1995: para 65). The societies that Debord has in mind here are the industrially advanced capitalist societies of the West. 'The concentrated...spectacle', Debord claims, 'normally characterizes bureaucratic capitalism, though it may on occasion be borrowed as a technique for buttressing state power over more backward mixed economies, and even the most advanced capitalism may call on it in moments of crisis' (1995: para 64). The societies that Debord has in mind here are those of the 'communist' bloc (in the USSR, Eastern Europe, China etc), Fascist regimes in industrially advanced societies -in times of crisisand an assortment of societies in the less industrially developed world.

3. Debord claims in Comments on the Society of the Spectacle that: 'When the spectacle was concentrated, the greater part of surrounding society escaped it; when diffuse, a small part; today, no part' ([1988] 1990: 9). Also see note 31 about spectacular images.

4. Debord maintains, in this regard, that as illegality in integrated spectacular society has increasingly encroached upon the 'legal state', the Mafia, with its secretive form of organization and ruthless methods (e.g., assassination), thrives. And it prospers in various guises, including the Mafia of the media, politicians, bankers, etc (1990: 63-71). 'The Mafia', Debord remarks, 'is not an outsider in this world...it stands as the model of all advanced commercial enterprises' (1990: 67).
5. Note, here, that these shared historical features of France and Italy that Debord mentions could, arguably, be considered common to the societies of the Eastern bloc. Nevertheless, Debord does not claim that the integrated spectacle was pioneered by Eastern bloc societies.

6. (i) An eternal present: in his early oeuvre (see note 8) Debord suggests that ' $[t]$ otalitarian bureaucratic society lives in a perpetual present in which everything that has happened earlier exists for it solely as a space accessible to its police' (1995: para 108). Here, the idea is that history, within the Stalinist regimes of the concentrated spectacle, was continually rewritten and memories controlled -'using police methods to transform perception' (1995: para 105). What emerged, then, was a seemingly eternal present watched over by the constantly vigilant forces of 'the police.' The feature 'an eternal present' is also implicit in Debord's discussion of 'consumable pseudo-cyclical time' (1995: para 153); a form of time found in both diffuse and concentrated societies. He suggests that time in the realm of consumption draws upon the cyclical time of static pre-industrial societies; in such societies time was dominated by the changing of the seasons and was experienced as something that returned to the mass of the population. Yet, it is a false form of cyclical time: with the rise of capitalism the attempt to present time as something that returns to people is at odds with the real historical time that capitalism has brought into existence for all individuals in society.

(ii) Generalized secrecy: I think that this feature is implicit in the Situationists' early oeuvre. For instance, just as Debord, in his later oeuvre, talks of 'the often frightening secrets of shoddy production hidden by advertising' (1990: 52), so the Situationists, in their earlier oeuvre, also make reference to how advertising acts to conceal, from consumers, the reality of the goods that are sold to them and the process of their production -whether in the diffuse or concentrated forms of spectacle (see, for instance, Debord's The Society of the Spectacle (1995: para 69) \& 'The Situationist Frontier', Internationale situationniste \# 5 trans. Paul Hammond, December 1960, http:// www.cddc.vt.edu/sionline/si/frontier.html Retrieved 24 May 2012). Likewise, just as Debord, in the 1980s, wrote that ' $[\mathrm{e}]$ veryone accepts that there are inevitably little areas of secrecy reserved for specialists' (1990: 
$60-1$ ), so the Situationists, in the 1960 s, allude to secrecy when discussing the 'specialized thought of the spectacular system' (Debord 1995: para 196).

(iii) Integration of state and economy: Debord, in a rather sweeping comment that could apply to both diffuse and concentrated societies, asserts that continual tinkering by the State has succeeded in compensating for the tendency for [economic] crises to occur' (1995: para 82). Concerning the Stalinist societies of the concentrated spectacle, Debord claims that the form of capitalism in existence was a bureaucratic or state capitalism (1995: para 104). Debord also claims that a characteristic of fascist societies, which he groups within the concentrated spectacle, was 'massive State intervention' in the capitalist economy (1995: para 109). Furthermore, in what I think is an allusion to some 'third world' societies, Debord claims that ' $[t]$ he concentrated form of the spectacle...may on occasion be borrowed as a technique for buttressing state power over more backward mixed economies' (1995: para 64).

(iv) Unanswerable lies: See note 9 for details.

7. For references to the inferior economic development of concentrated spectacular societies, compared with that of diffuse spectacular societies, see, for instance, Debord, The Society of the Spectacle (1995: paras 58, 104, 108).

8. By the early and later oeuvre of Debord and the Situationists, I mean the following. The early oeuvre refers to the writings of Debord and the Situationists up until the dissolution of the SI in 1972. The late oeuvre refers to Debord's writings in the post-SI period.

9. In his later oeuvre Debord claims that: 'Unanswerable lies have succeeded in eliminating public opinion, which first lost the ability to make itself heard and then very quickly dissolved altogether' (1990: 13). In his earlier book, The Society of the Spectacle, the feature 'unanswerable lies' is, I think, implicit in his claim that with the rise of spectacular society 'all community and critical awareness have ceased to be' (1995: para 25). Taking into account this claim - as well as others within Debord's early oeuvre, I think that 'unanswerable lies' can be considered a feature of the spectacle in its diffuse and concentrated forms.

10. Debord makes this remark in the 'Preface to the Third French Edition' of The Society of the Spectacle.

11. For references to Freud's pleasure-principle in the Situationists' oeuvre, see Raoul Vaneigem The Revolution of Everyday Life ([1967] 1994: ch 23).

12. I think that when the Situationists refer to the spectacle harnessing the passions of creativity, play and love, they allude to the notion that it manipulates the sexual instinctual drive.

13. I have discussed the Situationists' concept of 'spectacle' developed in their early oeuvre elsewhere. See, Julian Eagles, 'The Spectacle and Détournement: The Situationists' Critique of Modern Capitalist Society',
Critique: Journal of Socialist Theory,40:2 (May 2012), 179-198.

14. Debord uses the term 'image-objects' in The Society of the Spectacle (1995: para 15).

15. In The Society of the Spectacle Debord argues that for capital accumulation to continue in a society saturated with commodities, 'alienated consumption is added to alienated production as an inescapable duty of the masses' (1995: para 42).

16. Debord uses the term 'pseudo-gratification' in The Society of the Spectacle (1995: para 59). I should also add that Debord does not believe that all images are false. As he writes, in Panegyric Volume 2: 'The reigning deceptions of the time are on the point of making us forget that the truth may also be found in images. An image that has not been deliberately separated from its meaning adds great precision and certainty to knowledge' ([1997] 2004: 73).

17. The Situationists argue that there is one role that goes beyond fragmented roles -the role of the consumption celebrity. The consumption celebrity has access to the whole realm of consumption and appears to be an individual who is totally fulfilled. People find celebrities to identify with and live vicariously through such 'stars of consumption' (Debord 1995: paras 60-1).

18. Debord believes, I think, that for each individual to achieve complete self-realization humankind must make full use of the technology and productive powers that it has as its disposal. See, Ken Knabb ed., Situationist International Anthology ([1981] 2006: 135, 179-80).

19. In this article I assume that the Situationists accept Freud's earlier dualistic model of the instincts; that is to say, a sexual instinct and a self-preservation instinct. Vaneigem, I should point out, suggests that Freud made a 'mistake' with his later formulation of a death instinct (1994: 162).

20. In his earlier book The Society of the Spectacle, Debord claims that in the concentrated spectacle '[the bureaucratic economy] must... be attended by permanent violence' (1995: para 64). The implication, here, is that fear assists with the functioning of the concentrated spectacle. Concerning the diffuse spectacle and fear, see note 21 .

21. In their earlier oeuvre, the Situationists allude to the idea that fear plays a minor role in the functioning of diffuse spectacular societies. For instance, Vaneigem, in The Revolution of Everyday Life, writes 'that a whole spectacle is organised around particular sufferings. A sort of nationalised philanthropy impels each person to find consolation for his own infirmities in the spectacle of other people's. Consider disaster photographs, stories of cuckolded singers, or the grotesque dramas of the gutter press. And, at the other end of the scale, the hospitals, asylums and prisons -real museums of 
suffering for the use of those whose fear of going in there makes them rejoice to be on the outside' (1994: 47).

22. The Situationists claim that the 'new proletariat' includes workers (in blue and white collar employment) as well as groups on the margins of capitalist society for instance, youth, students and the lumpenproletariat. Also see note 38 .

23. Debord also suggests, in the script for his film 'Refutation of All the Judgements, Pro or Con, Thus Far Rendered on the Film The Society of the Spectacle' (1975), that ' $\mathrm{t}] \mathrm{he}$ spectacle is an infirmity more than a conspiracy' ([1978] 2003: 112). What Debord implies here, I think, is that for modern capitalist society to function successfully, what is most significant is that individuals, themselves, are attracted to, or tempted by, the (controlled) pleasures of the spectacle -its roles, lifestyles and consumer goods.

24. See the Guardian newspaper articles on this issue www.guardian.co.uk/environment/mark-kennedy Retrieved, 24 May 2012.

25. Another danger or risk that could be added here is that of AIDS. In this connection, I should point out that Debord expressed his admiration for Michel Bounan's book Le Temps du SIDA (1990) - a book that deals with the AIDS crisis. The book has not to date been translated into English. For further details, see Andrew Hussey The Game of War: the Life and Death of Guy Debord (2001: 363). For Debord's letters sent to Bounan see Notbored http://www.notbored.org/debord.html Retrieved, 24 May 2012.

26. I do not think that Debord believes that the mass media constitute some form of dictatorship or conspiracy. For instance, when commenting on the media's presentation of events, in Comments on the Society of the Spectacle, Debord claims: '...we know, for example, that a political assassination can be presented in another light, can in a sense be screened... And it is not some kind of reign of terror which forces such explanations on the media' (1990: 67). The implication here, I think, is that the mass media have simply highlighted various dangers to humankind, post 1968 , because such images are the sort of thing that help to stabilize modern capitalist society.

27. See, for example, the BBC News report http:// news.bbc.co.uk/1/hi/world/americas/2133626.stm Retrieved, 24 May 2012.

28. See, for example, the Sky News report http://news.sky. com/home/world-news/article/16165408 and the BBC News report http://bbc.co.uk/news/world-asia-17312913 Retrieved, 25 May 2012.

29. See, for example, the ABC News report http:// abcnews.go.com/wnt/video/osama-bin-laden-deathobama-calls-it-a-good-day-13510230. Retrieved, 25 May 2012.
30. The Situationists, in their early oeuvre, claim that the Marxian 'schema of the contradiction between productive forces and production relations should obviously no longer be understood as a short-term death warrant for the capitalist production system', and that ' $[t]$ his contradiction should be seen rather as a judgement...against the miserable development generated by this self-regulating production...in view of the fantastic potential development that could be based on the present economic infrastructure' (Knabb ed. 2006: 135). What I think the Situationists imply, here, is that in a context in which economic productivity has increased in advanced capitalist society, technological rationality cannot provide the basis for a critique of capitalist society -as was the case for Marx. In other words, it is not now the case that capitalism is unable to utilize successfully the technologies it has developed. Rather, the contradiction is the calamitous impact upon human society of the successful use of such technologies. For a discussion of how, for Marx, technological rationality could provide the basis for a critique of capitalist society, given the level of development of capitalism in the nineteenth century, see Andrew Feenberg 'The Bias of Technology' in Robert Pippin et al. Marcuse: Critical theory and the Promise of Utopia (1988).

31. Spectacular images, for Debord, are an 'abstract representation' of the entirety of the commodities of modern capitalist society. In such a society, exchange value has increasingly come to control and manipulate use value - see The Society of the Spectacle (1995: paras 46-9) \& Knabb ed. (2006: 136).

32. In Comments on the Society of the Spectacle, Debord notes that the spectacle's control of historical memory mystifies rulers as well as the ruled. As he writes: '...once the running of a state involves a permanent and massive shortage of historical knowledge, that state can no longer be led strategically' (1990: 20).

33. The Situationists were aware of Wilhelm Reich's ideas and references to Reich and his ideas can be found in various Situationist texts. As Reich's The Mass Psychology of Fascism was first published in the French language by Payot in 1972, it seems unlikely that this book, at least until 1972, would have been available to the Situationists.

34. For a more detailed discussion of this argument see Eagles, 'The Spectacle and Détournement', op.cit.

35. See Sigmund Freud 'Formulations on the Two Principles of Mental Functioning' (1911) in On Metapsychology: The Theory of Psychoanalysis (1991: $35-44)$.

36. I think that the manipulation of the selfpreservation instinct can be read into the Situationists earlier thought. It is, nevertheless, a factor that is more peripheral to the functioning of the spectacle in the Situationists' earlier oeuvre. 
37. In their early oeuvre, the Situationists claim that proletarian revolution is highly likely to take place against spectacular society. That said, they also claim that in France during 1968 '[a] lasting revolutionary victory was...only a very slim possibility' (Knabb ed. 2006: 317). For further details, see Eagles, 'The Spectacle and Détournement', op.cit.

38. For references to the term 'new proletariat' in the Situationists' oeuvre, see, for instance, Knabb ed. (2006: 111, 122). For further details about the 'new proletariat', see Debord (1995: paras 114-15).

39. For a discussion of commodity fetishism, see Norman Geras, 'Essence and Appearance: Aspects of Fetishism in Marx's Capital', New Left Review 65 (1971) 69-85. For Geras, 'the phenomenon of fetishism imposes itself on men (a) as mystification and (b) as domination'; '...the two aspects', he suggests, 'are intimately related'.

40. The Situationists, in their earlier oeuvre, claim that: 'The internal defect of the [spectacular] system is that it cannot totally reify people; it also needs to make them act and participate, without which the production and consumption of reification would come to a stop' (Knabb ed. 2006: 106). What underlies this claim, I think, is a conception of human nature that draws upon that advanced by Karl Marx. The Situationists and this is implied in Debord's later oeuvre - outline, following Marx, an 'essentialist' element to the nature of human beings; that is to say, the needs for nourishment and shelter and the capacities for love and creativity. Going beyond Marx, however, the Situationists add the capacity to play as an 'essential' aspect of human nature.

41. The Situationists' conception of proletarian revolution is more wide-ranging than that put forward by classical Marxists. They hold to the classical Marxist notion of the proletariat's seizure of control of the means of production. Yet, they also think that other forms of power, which classical Marxists believe are more marginal, such as alienated leisure, the urban planning system, the educational system and so on, need to be subverted to ensure that a proletarian revolution is authentic.

42. To quote Debord from Comments on the Society of the Spectacle: 'If history should return to us after this eclipse, something which depends on factors still in play and thus on an outcome which no one can definitely exclude, these Comments may one day serve in the writing of a history of the spectacle' (1990: 73).

43. Lest there be any confusion here, I should point out the following: although it might be thought that integrated spectacular society's encouragement of proletarians to become more aware of the specificity of their desires will increase the likelihood of proletarian rebellion, I do not think this is what Debord implies. Rather, the implication is that the spectacle has become more sophisticated in the way in which it harnesses the passions or real desires of individuals, given that it can now offer to consumers a greater range of commodities: proletarians, therefore, are subjected to a more intensified mystification. Furthermore, should large-scale proletarian rebellion actually take place against the integrated spectacle, I think that Debord still confronts the same problem found in his earlier thought; that is to say, that the majority of those in rebellion remain vulnerable to the recuperative powers of the spectacle.

44. In various passages within his oeuvre, Debord refers to the term 'innovation' vis-à-vis the revolutionary transformation of society. See Debord Complete Cinematic Works: Scripts, Stills, Documents ([1978] 2003: 147-48) \& Knabb ed. (2006: 176).

45. To quote Vaneigem from The Revolution of Everyday Life: '...within the [teenage] gang, playing remains of such great importance that a real revolutionary consciousness is always a possible outcome...Should delinquents arrive at a revolutionary consciousness simply through understanding what they already are, and by wanting to be more, they could quite conceivably become the catalyst of a widescale reversal of perspective' (1994: 242).

46. In The Society of the Spectacle Debord refers to spectacular rebellion or dissent, as opposed to genuine dissent, as follows: 'A smug acceptance of what exists is likewise quite compatible with a purely spectacular rebelliousness, for the simple reason that dissatisfaction itself becomes a commodity as soon as the economics of affluence finds a way of applying its production methods to this particular raw material' (1995: para 59). And again: 'By eagerly embracing the machinations of reformism or making common cause with pseudo-revolutionary dregs, those driven by the abstract wish for immediate efficacity obey only the laws of the dominant forms of thought, and adopt the exclusive viewpoint of actuality' (1995: para 220).

47. In their early oeuvre, the main thrust of the Situationists' thought suggests that proletarian revolutions are created by the spontaneous action of proletarians along with the (somewhat minimal) assistance or intervention of a revolutionary avantgarde.

48. For the Situationists, détournement is 'the reuse of preexisting artistic elements in a new ensemble' (Knabb ed. 2006: 67). They claim, in their early oeuvre, that if a majority of proletarians practise the technique of détournement, by constructing situations, modern capitalist society may be completely overturned. As regards the construction of situations, they write: 'The situation is...designed to be lived by its constructors. The role played by a passive or merely bit-part playing "public" must constantly diminish, while that played by those who cannot be called actors, but rather, in a new sense of the term, "livers," must steadily increase... Our situations will be ephemeral, without a future. Passageways. Our only concern is real life; we care nothing about the permanence of art or of anything else' (2006: 41) 
49. See the Situationists' assessment of the uprising of May 1968 in France and that of the Watts riots in Los Angeles during 1965, in Knabb ed. (2006: 194-203, 288325) \& René Viénet Enragés and Situationists in the Occupation Movement, France, May'68 ([1968] 1992).

50. See Debord (1995: paras 119, 120, 121); Vaneigem (1994: 199, 273); Knabb ed. (2006:.112-13, 285-86, 38082). Also see, Eagles, 'The Spectacle and Détournement', op.cit.

51. For a discussion of the Situationists' views about proletarian rebellion and consciousness put forward in their early oeuvre, see Eagles, 'The Spectacle and Détournement', op.cit.

52. The use of the internet's social networking sites - such as Facebook, Twitter, YouTube - to mobilize people has also been seen in the uprisings of the 'Arab Spring. I should add here that Debord does not comment on the rise, in spectacular society, of religious fundamentalism. Debord and the Situationists did not imagine that religion would re-emerge, in a modern capitalist context, as a major force in political and social life. For a discussion of this issue, in relation to the September 11, 2001 attacks in the US, see Eagles, 'The Spectacle and Détournement', op.cit.

53. See the Guardian newspaper article 'Why BlackBerry Messenger was rioters' communication method of choice' http://www.guardian.co.uk/uk/2011/dec/07/bbmrioters-communication-method-choice. Retrieved, 24 May 2012.
54. Concerning the destruction of property and looting that took place during the Watts riots of 1965, Debord remarks that: 'People who destroy commodities show their human superiority over commodities. They stop submitting to the arbitrary forms that distortedly reflect their real needs... Once it is no longer bought, the commodity lies open to criticism and alteration, whatever particular form it may take... Looting is a natural response to the unnatural and inhuman society of commodity abundance' (Knabb ed. 2006: 197) And concerning the theft of goods 'from a distribution factory (i.e. supermarket, large store, discount warehouse)' (Vaneigem [1974] 1990: 14), Vaneigem remarks that: 'What is required if an object is to be removed from the commodity process and kept from returning to that process, is obviously that it should not be re-sold, nor appropriated for individual use, nor exchanged for a mess of money or power, (stealing so as to play the underworld big-shot and thus to have a role is merely to reproduce the spectacle-commodity process, with or without the permission of the State)' (Vaneigem 1990: 13).

\section{References}

Debord, Guy. [1988] 1990. Comments on the Society of the Spectacle, translated by Malcolm Imrie. London: Verso.

[1967] 1995. The Society of the Spectacle, translated by Donald Nicholson-Smith. New York: Zone Books.

[1978] 2003. Complete Cinematic Works: Scripts, Stills, Documents translated by Ken Knabb. Edinburgh: AK Press.

[1989 \& 1997] 2004. Panegyric Volumes $1 \& 2$, translated by James Brook (volume 1) and John McHale (volume 2). London: Verso.

Eagles, Julian. 2012. 'The Spectacle and Détournement: The Situationists' Critique of Modern Capitalist Society. Critique: Journal of Socialist Theory,40:2, 179-198.

Freud, Sigmund. 1991. On Metapsychology: the Theory of Psychoanalysis, translated by James Strachey. Harmondsworth: Penguin.

Geras, Norman. 1971. 'Essence and Appearance: Aspects of Fetishism in Marx’s Capital'. New Left Review, 65: 69-85.
Hobsbawm, Eric. 1994. Age of Extremes: The Short Twentieth Century 1914-1991. London: Michael Joseph.

Hussey, Andrew. 2001. The Game of War: the Life and Death of Guy Debord. London: Jonathan Cape.

Knabb, Ken (ed). [1981] 1989. Situationist International Anthology, translated by Ken Knabb. Berkeley, CA: Bureau of Public Secrets.

[1981] 2006. Situationist International Anthology, translated by Ken Knabb. Berkeley, CA: Bureau of Public Secrets.

Pippin, Robert et al. 1988. Marcuse: Critical theory and the Promise of Utopia. London: Macmillan Education.

Reich, Wilhelm. [1933] 1991. The Mass Psychology of Fascism, translated by Vincent R. Carfagno. London: Souvenir Press.

Vaneigem, Raoul. [1974] 1990. Contributions to the revolutionary struggle intended to be discussed, corrected, and principally put into practice without delay, (written under the pseudonym Ratgeb) translated by Paul Sharkey. London: Elephant Editions. 
[1967] 1994. The Revolution of Everyday Life, translated by Donald Nicholson-Smith.London: Left Bank Books and Rebel Press.

Viénet, René. [1968] 1992. Enragés and Situationists in the Occupation Movement, France, May '68. New York: Autonomedia. 
